\title{
Drama barroco: topografias do tempo
}

\author{
Olgária Matos ${ }^{*}$
}

Resumo: Este artigo procura mostrar de que maneira Walter Benjamin trabalha com o conceito de aiegoria para o século XVII e seu sucedânio moderno - o fetichismo da mercadoria. Se Hamlet é o representante emblemático da melancolia, Baudelaire o é do mal-du-siècle. Para compreender o tempo histórico, Benjamin propōe interpretá-lo no interior do trabalho cultural do luto em sua expressâo máxima: a ruína.

História e Natureza ou Acaso e Necessidade transformam-se em natureza morta e s/lêncio enlutado dos homens na história: o necessitarismo exclui a contingência (na natureza) o acaso (na história). Ao tempo mecanizado dos relógios, Benjamin contrapóe uma modalidade de experiência do tempo que se expressa no déjà vu, temporalidade que vacila entre o já acontecido e o ainda náo manifesto. Trata-se de compreender a história simultaneamente como panorama das recordações e experiência de um limiar.

Palavras-chave: alegoria - melancolia - destino - acaso

"Os subúrbios são o estado de sítio das cidades, o campo de batalha onde se deflagra, ininterruptamente, o combate decisivo entre a cidade e o campo"

(W. Benjamin)

DAS PERIFERIAS TALVEZ SE POSSA DIZER serem elas a experiência de um limiar, como a que aproxima também séculos distantes em um campo visual. Trata-se do espaço imagético do teatro alemão do século XVII e seu sósia atual - as ruas de Paris. Cenários assemelham-se à alma dos atores, a melancolia a Hamlet, o maldu-siècle ao flâneur. No entrecruzamento dos dramas alemão e francês, reúnemse séculos distantes, constituem-se panoramas da memória, alegorias de reminiscências.

\footnotetext{
* Professora do Departamento de Filosofia da FFLCH-USP.
} 
Benjamin faz análogas historiografia e recordação (Erinnerung), descritas, ambas, como imagens do pensamento (Denkbilder), pensamentos em imagens ou ainda imagens em pensamento. São elas "parábolas secularizadas" (Bolle, 1994, p. 297). Elas oferecem a maneira pela qual épocas se autointerpretam, na correspondência entre "antigos rituais sagrados e o comportamento profano moderno" (Ibid.). Nos primeiros, a interdição das imagens, no segundo, a ausência de seus objetos: "não farás nem escultura, nem figura do que se encontra no Alto, nos céus, embaixo, na Terra". Com estas palavras, Deus proíbe aos homens, no Antigo Testamento, representar em imagens o divino a partir do "original". Deus manifesta-se ao homem pela Voz e por sinais. Assim dirige-se a Adão e Eva; ordena a Abraão o sacrifício de Isaac; envia as sete pragas ao Egito para punir o faraó; abre ao meio o Mar Vermelho e guia o povo eleito pelo deserto. Fala aos profetas sem jamais revelar sua imagem visível e seu rosto. O homem permanece no domínio da voz e dos enigmas. Mas não exatamente, pois, quando cria Adão, a Bíblia acrescenta que Ele o fez "à sua imagem e semelhança". Sendo Deus matriz primeira, Adão apresenta-se como uma espécie de cópia realizada, mas a exemplar único, inferior ao modelo. No fervor modelo divino é, paradoxalmente, cópia "original"e "autêntica". Seja no fervor da fé ou em imagens dessacralizadas, Benjamin reconhece um acontecimento comum, portador de um duplo significado: a Ausdrucklose (o "sem-expressão") - além de preceito religioso é "produção ativa" de ausências como fenômeno histórico. Ausências que o filósofo nos dá a conhecer na tarefa de traduzir uma língua em outra, uma época para outra: o confronto não se estabelece na relação entre original e tradução, mas em traduções sem original, ou melhor, no desaparecimento do original. Em Origem do Drama Barroco Alemão, o que permite ingressar na forma de uma escritura é a alegoria, alegoria que preserva na forma de "ruídos"a memória em relação a uma semelhança perdida. Reavê-la é traduzir a existência em algo legível, leitura do já-acontecido (das Gewesene) - do desaparecido, cujos rastros e imagens constituem, a um só tempo, configurações permanentes e efêmeras da vida - gestos e palavras, coisas e acontecimentos: "o corpo humano não poderia constituir uma exceção ao mandamento que impõe a destruição do orgânico de forma a que o verdadeiro significado, como foi escrito e fixado deve ser retirado de seus fragmentos (...); a alegorização da physis só pode ser compreendida em todo seu vigor em relação ao cadáver. E a morte barroca - porque ela é só isso - cadáver - assim pode entrar na pátria alegórica" (Benjamin, 1980a, p. 391-2). Interpretar alegoricamente o corpo como um texto a partir da desvalorização de seu sentido literal (e por isso mesmo um "ato de repressão") é ingressar nas ruínas de uma época, ruínas que se convertem na permanência inconsciente de uma época em outra. 
É assim que olhar o século XVII permite reencontrar o século XX, considerando naquele mais a representação protestante da miséria e ruína do homem e do mundo - o Deus feito homem é sacrificado - do que a insistência da ContraReforma em sua coerência e esplendor. Analogamente, Benjamin volta-se mais para os boêmios e flâneurs do Segundo Império do que aos imponentes monumentos da cultura dominante. Tratados como alegorias, personagens lembram, no melancólico século XVII, os "desamparados transcendentais" (transzendentalen Obdachlosigkeit) do século XIX. Menlancolia e mal-du-siècle fazem lembrar as ambivalências e contradiçöes dos heróis culturais alemães, particularmente Goethe, e Weimar, lugar do "classicismo alemão". O filósofo duvida desses heróis, tomando distância dos arquétipos do narcisismo oficial. Para compreender o seu tempo, propõe pensar a história no interior do trabalho cultural do luto ${ }^{1}$.

Alegoria primeira: a ausência de Deus. Dela resulta o despertar em meio "à arbitrariedade do reino de objetos mortos", no infinito de um mundo sem esperança e sem redenção. Neste horizonte inscreve-se a diferença entre drama barroco e tragédia clássica: "o herói trágico só tem uma linguagem que lhe convenha absolutamente: o silêncio (...). Com ele o herói rompe as pontes que o ligam ao Deus e ao mundo e se refugia na solidão glacial do próprio Eu. Ele nada sabe a respeito do que the é externo, pois sua solidão é absoluta. Como pode ele exprimir, senão pelo silêncio, essa solidão, esse desafio de suprema auto-consciência?" (Rosenzweig, F., apud Benjamin, 1984, p. 131). Se na tragédia o herói se reconhece superior a seus deuses, e se o tempo que lhe é próprio é a luz do dia, no drama barroco o tempo é noturno: nele há ruínas, esqueletos, crânios, espectros e fantasmas da escuridão em meio às quais a salvação 'recai inteiramente sobre o homem. Ruínas constituem um universo cultural onde se manifesta a estrutura sacrificial da história, em sentido próximo àquele que Nietzsche lhe atribui: "todas as vezes em que a humanidade achou necessário fazer-se a si mesma uma memória, isto nunca se realizou sem sangue e sem tormento" (Cf. Nietzsche, 1947). Para ele, "mascara-se com fogo algo a fim de que permaneça na memória e assim não deixe nunca de doer". Algo semelhante, Benjamin encontra em Kafka. A natureza do moderno mostra-se na Colônia Penal, na máquina que inscreve nas costas dos prisioneiros a lei que os condenou - de maneira a deverem decifrá-la nas próprias feridas, com o que se dá a conhecer, a um só tempo, sentença e sua própria morte: "Na Colônia Penal aqueles que têm o poder utilizam uma máquina arcaica que grava letras ornamentais nas costas do culpado, multiplicando as chagas de seu corpo e aumentando-as até o ponto em que as costas se tornam clarividentes, capazes por si só de descobrir a escrita para conhecer o nome da culpa desconhecida. Suas costas são sentenciadas" (Benjamin, 1980a, II). Esta escrita é "a forma que as coisas assumem uma vez esquecidas" (Idem, 1984, p. 431). O esquecido mistu- 
ra-se com o esquecimento de uma pré-história e o corpo surge como meio dessa distorção - com o que o corpo se torna estranho ao homem, um território estrangeiro embora intimamente seu. Esta é a forma de sua expressão - é expressão de sua reificação. O corpo não é mais "a beleza corporalmente viva" do Banquete, onde Platão alia o que é vivo (die Lebendigkeit) à sua radiosa aparência (der Schein). A aparência do Belo é a aparência do seu "estar vivo". Na modernidade, ao contrário, beleza, aparência e vida perdem sua harmonia, a morte é o que abruptamente separa a physis sensível e a significação supra-sensível: "é a morte que grava mais profundamente a tortuosa linha de demarcação entre a physis e a significação" (Benjamin, 1984, p. 188). À vivacidade e luminosidade da bela aparência - o corpo vivo - opõem-se a rigidez, a bela aparência em seu ocaso - a morte.

Tristeza é o nome da relação entre significação e natureza morta: "morte e significação constituem tanto produtos temporais do desenvolvimento histórico, como estão estreitamente imbricados um no outro no estado de pecado da criatura privada da Graça”" (Idem; tradução modificada). Fundando o conceito de história no "desamparo transcendental", quando ela adquire o caráter de natureza e esta funda-se no silêncio da queda do Paraíso, Benjamin mostra como a natureza se transforma em história, em história-natureza. Expulso o homem da cidade de Deus encontrou-se em um mundo desconhecido, ou melhor, sem explicação ou sentido. Desdivinizada a natureza pela Ciência Moderna, sua racionalidade desenvolve-se visando eliminar o acaso, na ordem da natureza, a contingência na história e a temporalidade instável e caprichosa - a fortuna - na ética e na política. $O$ cálculo e a previsibilidade dos fenômenos naturais passa a ocupar o lugar antes reservado à fé e à santidade. Contingência, acaso e fortuna retornam, porém, passando a constituir a "sombra" da Razão e da consciência desperta em estado de vigília. É assim que Hamlet no movimento mesmo da consciência e por força dela, ao raciocinar enlouquece. E mais: "a morte de Hamlet (...) é caracterísitca do drama barroco (...), já que Hamlet quer respirar o ar impregnado de destino. Quer morrer por obra do acaso" (Idem, p. 159).

Ao lado do acaso incontornável encontra-se a categoria barroca por excelência, a ruína. Natureza e história têm em comum a caducidade e a "lógica da destruição": "o que jaz em ruínas, o fragmento significativo: essa é a matéria mais nobre da criação barroca” (Idem, p. 200). A história profana é determinada pelo transitório e escreve-se com a linguagem da decomposição: "quando com o drama barroco a história penetra no palco, ela o faz enquanto escrita. A palvra história está gravada com os caracteres da transitoriedade no rosto da natureza" (Idem, p. 199). No drama barroco alemão as ruínas são o cenário de uma história fixa, imóvel - como a natureza inorgânica: "a fisionomia alegórica da natureza-histó- 
ria posta no palco pelo drama, só está verdadeiramente presente como ruína. Como ruína a história se fundiu sensorialmente com o cenário (...). As alegorias são no reino do pensamento o que as ruínas são no mundo das coisas" (Benjamin, 1984, p. 200). No drama francês as ruínas são internas ao "sujeito", são fragmentos de pensamento; as ruínas são atuais, existenciais atuais, são existenciais.

Em carta a Scholem (1935), Benjamin escreve: "Gostaria de lhe revelar ao menos isto: também aqui (na Obra das Passagens) haverá o desdobramento de um conceito tradicional. Se lá se considerava o conceito de Trauerspiel, aqui estará o de fetichismo da mercadoria" (Benjamin, CWB). Se o livro sobre o Trauerspiel desenvolveu o século XVII a partir da Alemanha a Obra das Passagens tratará do século XIX a partir da França". Alemanha e França: ambas são tomadas por um sono letárgico - a história natural ou história como destino: "(há aqui) a redução do conjunto de atores (agentes) da história a um só e mesmo agente universal: o destino, sugerida pela metáfora do teatro, uma das mais conhecidas alegorias da história" (Domingues, 1996, p. 99). Se a história é o "teatro do mundo", os acontecimentos são espetáculos, as ações dos homens são papéis desempenhados por atores. $\mathrm{O}$ autor - ou agente - é a história como destino, senhor este da vida e da morte. Há, aqui, assimilação total entre as leis físicas da natureza e as leis de ferro da história: "se a fisica tende a revestir em nossa imaginação a forma de um mandamento quando ela atinge uma certa generalidade, reciprocamente um imperativo que se dirige a todo mundo se apresenta um pouco para nós como uma lei da natureza. Ao se encontrarem em nosso espírito, as idéias se intercambiam. A lei pede ao mandamento o que ele tem de imperioso; o mandamento recebe da lei o que ela tem de inelutável" (Bergson, 1939, p. 5). Tudo se passa, sob a inexorabilidade do destino, como se as "forças das potências noturnas do tempo e do mundo dos homens" fosse o lugar "onde os mortos golpeiam os vivos".

A história-natureza é a da morte fisica sem oropéis, a morte exposta no desespero sem consolo, aquela que se mostra no esqueleto, história muda, intransmissível e sem recordações. Reúnem-se, aqui, três questões: esquecimento, memória e representação distorcida da história. Esta vive de uma ausência e é tomada pela tristeza e pelo luto do Deus que abandonou o mundo, redefinindo-se a categoria do tempo: seu emblema central é a caveira, alegoria que indica o fracasso da história, pois seu único "sentido" se resume na "produção do cadáver". Figura alegórica e emblema da modernidade "o objeto torna-se alegórico sob o olhar do melancólico (...), pois a alegoria é o único e poderoso divertissement que se oferece ao melancólico" (Benjamin, 1984, p. 163). Alegoria primeira, a Melancolia I de Dürer, portadora de figuras geométricas que constróem o espaço, mas também o tempo: a água corrente dá a "roda da vida", inelutavelmente descendente como a de todo ser humano: o relógio de sol marca o "tempo lunar"; a ampulheta mede 
o tempo transcorrido e o que ainda resta passar. Mundo sem Deus, conhecido através de sua geometrização, é também o cartesiano, onde a idéia de Deus comparece como inconsciente da Ciência, garantidor do desvendamento dos movimentos da Terra e do Céu pela razão humana. A geometrização do espaço, o cálculo geométrico-algébrico da luz não deixarão mais "nenhuma matéria de admiração". Os artefatos da geometria - compasso, esfera, triângulos, trapézios, retângulos, quadrados - culminam em um imenso poliedro. O "espírito de geometria" não é, porém, suficiente para combater a melancolia. Cercam-na, mas ela olha, perdida, para além do espaço e do tempo. "Inútil e incerto", dirá Pascal, é o mundo de Descartes provido de uma "divindade sem Deus". Descartes, em seus Meteoros vangloria-se de ter a tal ponto desvendado os mecanismos do céu, o que culmina em um "desencantamento sideral" melancólico, como é melancólica "a eternidade do homem pelos astros" - repetição impertubável e sem fim de movimentos circulares que repetem, no infinito, as "mesmas representações". O tempo da repetição é o tempo dos relógios e da história-natureza e esta é fatalidade do destino: "aqui jaz a orgulhosa mulher que pensava que o relógio de seu cérebro era suficientemente forte para mudar a trajetória dos astros" (Agrippa, apud Benjamin, 1984, p. 129).

Vinculando o teológico e o filosófico, racionalistas como Descartes e Leibniz vêem no mundo a obra de um Relojoeiro, e compreendido em termos de mecanicidade ponderada e repetitiva de ponteiros: "não há diferença alguma entre as máquinas construídas pelos artesãos e os diversos corpos celestes que somente a natureza compõe, a não ser esta: os efeitos das máquinas dependem apenas da ação de tubos ou molas e outros instrumentos que, devendo ter alguma proporção com as mãos daqueles que os constroem, são sempre tão grandes que tornam visiveis suas figuras e movimentos, ao passo que os tubos ou molas que produzem os efeitos naturais são geralmente pequenos demais para poderem ser percebidos por nossos sentidos" (Descartes, p. 321).

A adoção do relógio e da máquina para explicar a realidade física e biológica significa conhecer, segundo a forma de funcionamento, a máquina do mundo: "o critério do conhecer como fazer ou o da identidade entre conhecer e construir, vale tanto para Deus como para o homem (...). Daí a comparação entre o fazer de Deus e o fazer do homem (Rossi, 1989, p. 118-20).

"Deus é artífice, engenheiro e relojoeiro e a identidade entre conhecer e construir vale tanto para Deus como para o homem. Este se coloca no lugar de Deus, podendo conhecer o mundo como Deus o concebeu. Também a visão corpo e alma e a supremacia da alma pode ser comparada à imagem de dois relógios precisos e sincronizados, e o ponteiro dos segundos impóe seu ritmo ao funcionamento dos dois mundos: a imagem do movimento dos ponteiros, como demons- 
trou Bergson, é indispensável para a representação do tempo recorrente e não qualitativo da ciência matemática (...). Nesse tempo abstrato estão inscritas não somente a vida orgânica dos homens, como também as manobras do cortesão e as 'ações' do Príncipe que, segundo o modelo de um Deus que governa, intervindo em ocasiões específicas, interfere de forma imediata nos negócios do Estado, a fim de ordenar os dados do idem, processo histórico, numa seqüência regular e, por assim dizer, espacialmente mensural” (Benjamin, 1984, p. 163).

Assim considerado, o tempo é, para o espírito, a faculdade de exercer o "estado de exceção" - a ditadura. Esta é a função do Príncipe: instaurar o "estado de exceção", suspender as leis positivas em nome do "bem comum", e prolongá-lo até que, por terem-se os homens habituado a ele, se esqueçam que vivem em "estado de exceção": "o estado de exceção", escreve Benjamin, "é a regra" (Idem, 1980b, Tese VIII, p. 254). O "estado de exceção" mantém-se na medida em que se desconhece como tal. A melancolia do Príncipe e a traição do cortesão imobilizam a história na repetição dos mesmos gestos, na "ruína permanente" do desfecho dos dramas barrocos: "Caim foi o primeiro cortesão, porque a maldição divina o privou de qualquer pátria” (Antonio Guevara, apud Benjamin, 1984, p. 120).

O céu não é mais o firmamento de Deus, os astros não são mais seu milagre visível. É este o drama da modernidade. No Drama Barroco, o que importa não é tanto o gênero literário quanto a representação que realiza da Reforma e do radicalismo dos luteranos alemães: "negando às obras o efeito miraculoso, abandonando à graça da fé, e fazendo do domínio secular e político o lugar da provação de uma vida que só indiretamente é religiosa mas na verdade destinada a testemunhar virtudes burguesas - o luteranismo instalou certamente no povo um sentido rigoroso da obediência ao dever, mas entre os grandes, em contrapartida, a melancolia" (Benjamin, 1984; p. 161, tradução modificada). A melancolia é a dimensão política da modernidade, pois há, nela a desvalorização da vida na fé ascética. A melancolia moderna, diversamente da acedia teológica, independe de qualquer tradição médica. Ela é a configuração de uma sensibilidade exacerbada, de uma reflexão prostrada, da consciência da transitoriedade e da tensão entre tempo e eternidade. No luteranismo, Benjamin reconhece, como Weber o demonstrou, o culto secular da cidade dos homens, isto é, suas ruínas. Estas constituem o objeto "a priori" da disposição anímica. As leis do Trauerspiel provêm do âmago da tristeza pois o mundo não se expressa nele preservando a relação de sujeito e objeto; confirma-se, ao contrário, a dissolução dessa oposição pois o "sujeito" imerge nas profundezas de seu objeto: "a meditação é própria do enlutado. No caminho para o objeto - ou melhor - dentro do próprio objeto” (...) há um sentimento dissociado do sujeito empírico e vinculado, por um nexo interno, à plenitude de um objeto" (Idem, p. 163). 
Um tal saber não pode admitir a ficção teórica de uma distância metodológica frente à objetividade. Que se retomem as referências reiteradas a Hamlet e outros heróis shakespeareanos, oscilando sempre entre o ser e o não-ser, falidos de seu próprio destino: "nunca vi dia mais belo nem mais horrendo que este", exclama Macbeth. E o rei Lear perguntando a sua filha Cordélia viva: "quando morreste?". Isto significa: o homem moderno não se circunscreve mais no domínio do que é. Sem Deus, o homem está à deriva, enredado nas tramas que o dominam e sobre as quais não tem nenhum poder. O tempo não é só breve e os homens, mortais. É também o "tempo de homens partidos" nos quais a melancolia é a consciência assombrada pela fortuna: "Hamlet não é fatalizado pelos céus", escreve Leda Tenório da Motta, "mas joguete de si mesmo (...). A hesitação mostra, justamente, que se move no terreno do livre-arbítrio (...). Hamlet não é um homem, mas todos os homens, por sua não-justificação, por sua não explicação, por sua deriva em cena" (Mota, 1997, p. 48). A necessidade de responder à instabilidade do tempo histórico e às incertezas do presente resolve-se, no plano racionalista, na exclusão teórica da fortuna, pois o agente ético e político "está encravado entre dois poderes exteriores que o determinam de maneira exatamente oposta: a necessidade o obriga a seguir as leis (naturais) e regras (históricas) sobre as quais nada pode; a contingência o força em direções contrárias imprevisíveis, dando peso aos versos de Ovídeo nas Metamorfoses: "vejo o melhor e aprovo, mas sigo o pior" (Chauí, 1996, p. 19-20).

O abandono do homem em "estado de criatura" põe fim à harmonia préestabelecida por um intelecto divino. Os conflitos não caem mais do céu. Neste labirinto de vacilações há uma particular tristeza, pois vive-se com a consciência da inadequação do sujeito ao mundo. Eis o que afeta sua vitalidade. Entre o ser e o não-ser, há o temor da perda de identidade ou de ser absorvido pela identidade de um outro - no limiar do abismo da indiferenciação: a morte. Esta não é a negação da vida mas seu extremo, assim como o esqueleto é o limite orgânico de um corpo já inorgânico. Natureza e história retornam, no barroco, à pré-história, à fixidez mítica, como a dos cenários da morte barroca. A transposição do conceito de natureza em conceito histórico é o tema central da filosofia da história benjaminiana.

Se a melancolia é a personagem principal dos dramas, é por seu enigma, enigma de ser uma "tristeza sem causa". Sentimento da precariedade da vida, o único prazer do melancólico é o estudo solitário. Por isso, Benjamin observa a diferença entre o Renascimento e o Barroco: "enquanto o primeiro indaga o universo, o Barroco explora as bibliotecas. Sua meditação tem o livro como correlato (..). O Livro da Natureza e O Livro dos Tempos são objetos da meditação barroca (...). O livro era considerado um monumento permanente ao teatro da nature- 
za, rico em coisas escritas" (Benjamin, 1984 p. 164). Explorar bibliotecas requer o empenho paciente que possa ignorar a barreira do tempo, a separação entre antigos e modernos, bem como as diferenciações entre mitos, lendas, citações e aforismos; explorá-la significa também recolher, vagarosamente, um mundo disperso, mas sobretudo submeter-se a uma ordem sempre provisória e à iminência da desordem oculta em algum texto inesperado. É, além disso, vacilar entre a acumulação e a anarquia, transformar a companhia em solidão e esta em companhia. Nem a desagregação nem a desordem podem interromper este operação entendida como metáfora do trabalho melancólico. "Para o melancólico, o mundo é apenas um objeto de saber que se aninha nos edificios convertidos em ruínas" (Idem, p. 199200). Estas são histórias sedimentadas, sob a ameaça constante de converter-se em natureza e esta em história necessitarista, a-histórica: "a questão da necessidade das manifestações históricas é sempre claramente apriorística” (Idem, p. 74).

A necessidade opõe-se ao mero acaso, para contrarrestar o sentimento agudo do exílio do homem no mundo. O espaço e o tempo devem combinar acaso e necessidade para "segurar nas mãos os acontecimentos históricos como um cetro". Para isso reúnem-se o cientificismo das ciências da natureza e filosofia política: "a função do tirano é a restauração da ordem durante o estado de exceção: uma ditadura cuja vocação utópica será sempre a de substituir as incertezas da história pelas leis de ferro da natureza" (Idem, p. 97). À estabilização do "estado de exceção" na vida política corresponde a estabilização interna equivalente, "o controle das emoções, num estado de exceção dentro da alma” (Idem). Tais dispositivos visam enfraquecer o acaso - acaso que se constitui como uma inconveniência face ao necessitarismo histórico. Na tripartição do tempo - passado, presente e futuro revela-se a melancolia; os melancólicos vivem antecipadamente um futuro que se tornará passado - diante de que ações e escolhas se equivalem. Razão também de os dramas barrocos serem dramas de destino, destino de morte. Se a subjetividade barroca despedaça, fragmentada, faz-se visível nos cenários em ruína, ela é a de Iago que diz, ao final do Otelo "não sou quem eu sou".

A de Baudelaire lhe é análoga: seu hábito de "trocar de máscara" revela uma "identidade" provisória. E, da mesma forma que o cenário barroco é uma "paisagem originária petrificada" no palco, a divisão social do trabalho na fábrica proletária se transfigura na rua burguesa, onde a personagem principal amorfa e anônima é a multidão. À melancolia do Príncipe corresponde, na modernidade, o tédio que resulta do processo de producão repetitivo. Este é a infra-estrutura cuja expressão super-estrutural é a rua: "o trabalho fabril é a infra-estrutura do tédio ideológico das classes altas" (Benjamin, 1980a, V, p. 1162). Seus novos templos são as Passagens de Paris, o profano que toma o lugar do sagrado: "sem dúvida, nosso tempo", escreveu Feuerbach, "prefere a imagem à coisa. A ilusão é sagrada, 
a verdade profana”. Isto significa a entronização do divino em objetos inanimados, a radicalização do fetichismo: "(na modernidade) o referencial deixa de ser o trabalho - tanto como força de trabalho quanto como cristalização dos produtos para ser consumo, ou o que Marx chamava de "fetichismo da mercadoria" (Chauí, 1996, p. 22). A Ciência Moderna, por sua vez, transforma o mundo para torná-lo inteligível, controlável e seguro, mesclando-se, em sua racionalidade, mesclam-se humanização (reconhecimento de si na exterioridade) e teofania (manifestação de Deus na Criação). O que significa reconhecer nas sociedades industriais desdivinizadas pela laicização efeitos religiosos que tendem a fazer surgir no real prosaico do mundo, em meio aos homens, a presença de "Deus".

Um novo ardor, agora fetichista, encontra-se, para Benjamin, nas exposições universais da segunda metade do século XIX europeu, o culto ao divino convertese em rituais ligados à veneração de artefatos industriais - as mercadorias. Toda a Europa deslocou-se para contemplá-las na exposição parisiense de 1855, que recebeu mais de seis milhões de visitantes. Grande espetáculo é também oferecido pelas galerias, construções em ferro e vidro, "aquários humanos", no dizer de Benjamin, onde se acumulam mercadorias, jogadores, vitrines e prostituição. "Paris, Capital do Século XIX" é sobretudo a "Capital do Capital". Novas catedrais - as passagens; esțas são, semelhantemente à "féerie" das estradas de ferro e de suas estações, lugares de culto. O filósofo as descreve, com funções intercambiáveis; a Catedral de Marselha é descrita como estação ferroviária e vice-versa. Marx falava das "sutilizas metafísicas e argúcias teológicas" que se inscrevem nas mercadorias. Animismo, fetichismo, totemismo ressurgem nas mercadorias: "toda a vida das sociedades nas quais reinam as modernas condições de produção apresenta-se como um imenso acúmulo de espetáculos" (Debord, 1997). Lugares de culto transformam-se em lugar de "exposição" de um edifício, de uma construção: "Há uma grande diferença entre os antigos iconoclastas de igrejas e o alto grau de abstração que permite a um artilheiro da Guerra Mundial considerar uma catedral gótica como simples referência em sua área de tiro" (Jünger, 1989). O mundo abstrato é o resultado de sua desertificação técnica, como é abstrato o homem convertido em conceito. Sua base comum - o fetichismo: "o animismo animou a coisa, o industrialismo coisificou as almas” (Horkheimer e Adorno, 1986, p. 27-8).

Indiferença entre coisas e coisas, homens e homens, homens e coisas é o mundo do mercado mundial e o da ciência planetária: "sem pretender aproximarme minimamente do significado das causas econômicas da guerra", escreve Benjamin, "podemos afirmar que a guerra imperialista, no que tem de mais terrível, de mais fatal, é codeterminada pelo abismo entre os gigantescos meios da técnica de um lado e sua exígua iluminação moral, de outro" (Benjamin, C.R., p. 149-50). A associação entre a ciência e a guerra ou o vínculo entre progresso e regressão dá-se 
no apogeu do desenvolvimento do domínio humano sobre a natureza. A idéia de progresso é um dos mais poderosos narcóticos do século. Eis por que Benjamin faz contemporâneos o século XVII e o século XIX, a pré e a pós-história da modernidade na modernidade. No tempo mítico - o da repetição - todas as épocas são contemporâneas. Tempo mítico significa o sono, o "ainda não", aquele momento não realizado do passado, mas também o "cedo demais" para a autoconsciência da modernidade. Quanto mais profundo é o sono, mais distante é o despertar; e, assim como o sono se torna sonho, o sonho vem a ser fantasmagoria. $\mathrm{Na}$ Obra das Passagens, as arcadas de Paris constituem a fusão da modema tecnologia com o sonho arcaico: "o descompasso entre a tecnologia futurista do capitalismo e sua consciência coincide com o reencantamento da modernidade na fantasmagoria das mercadorias e também com a produção de imagens de desejos intrincados com elementos da história originária (Ur-Geschichte), com o armazenamento de potencialidades utópicas disponíveis à liberação" (Steinberg, 1996, p. 35). Esta oferece-se por sinais. Em "Destino e Caráter" - ensaio no qual Benjamin os concebe como esferas conceitualmente separadas - o caráter não se relaciona causalmente com o destino: "tal como o caráter, o destino também pode ser apreendido por sinais, nunca cm si mesmo". O caráter pode ser apreendido na fisionomia, o exterior que corresponde ao interior, "o interno ao homem é explicado pelo externo” (Cf. Matthieussent, 1994 e Bolle, 1994, p. 40-2) pois há uma adequação, segundo os fisionomistas do século passado, entre os traços de um rosto e seus caracteres psicológicos. Os indivíduos "carregam" consigo qualidades e defeitos estampados no rosto: os traços não mentem, o rosto revela a alma inteira. Mas, a cada instante, o rosto diz outra coisa diferente de si mesmo, ele é a alegoria da verdade psicológica de um indivíduo. Em "Paris, Capital do Seculo XIX", Benjamin observa que "o colecionador é o fisionomista do mundo das coisas; por detrás da aparência de um objeto, o colecionnador adivinha sua alma e chega a pressentir seu destino. Sinais fisionômicos são marcas que falam, vozes que se escutam antes de seu tempo. Assim pode-se conhecer o destino através de signos, caso se saiba como os ler e quando fazê-lo, pois o futuro só é atraído para o presente num instante ou cintilância que não se repetem jamais" (Cf. "Madame Ariadne, segundo pátio à esquerda”. In: Benjamin, 1994).

Destino e caráter só coincidem na instantaneidade da "presença de espírito" (Geistesgegenwart): "(a presença de espírito) só consegue estar presente (...) na medida em que penetra no tom da voz, no sorriso na mudez, no olhar, no gesto. Pois a presença de espírito existe apenas graças ao corpo" (Benjamin, 1985). Separados, presença e espírito, o destino é infortúnio, é a esfera da vida culpada; quanto ao caráter, é inocência, felicidade: "felicidade é o que libera o homem do enca- 
deamento do destino e da trama de seu próprio destino" (aus der Schicksale und aus den Netz dem eignen", 1980a II, p. 174)2.

Neste horizonte, Benjamin inscreve a sensação do déjà vu, fenômeno vinculado à atemporalidade do inconsciente: "já foi descrito muitas vezes o déjà vu. Será tal expressão realmente feliz? Não se deveria antes falar de acontecimentos que nos atingem na forma de um eco, cuja ressonância parece ter sido emitida $\mathrm{em}$ um momento qualquer na escuridão da vida passada? Além disso, acontece que o choque com que um instante penetra em nossa consciência como algo já vivido, nos atinge, o mais das vezes, na forma de um som. É uma palavra, um rumor ou um palpitar, aos quais se confere o poder de nos convocar desprevinidos ao frio mausoléu do passado, de cuja abóboda o presente parece ressoar apenas como um eco. Estranho que ainda não se tenha buscado o sósia desse êxtase: o choque com que uma palavra nos deixa perplexos tal qual uma luva esquecida em nosso quarto. Do mesmo modo que esse achado nos faz conjecturar sobre a desconhecida que lá esteve, existem palavras ou silêncios que nos fazem pensar na estranha invisível, ou seja, no futuro que se esqueceu junto a nós ("Infância Berlinense". In: Benjamin, 1994, p. 89).

Benjamin, referindo-se ao fenômeno do déjà vu, interroga, de início, a própria expressão: tratar-se-ia de uma modalidade de experiência do tempo que não teria sido suficientemente analisada: "será esta expressão realmente feliz?" Para melhor a compreender, Benjamin utiliza-se de uma metáfora sonora - espécie de paradoxo, já que o déjà vu diz respeito à visão. O filósofo assim entende a possibilidade de sermos transportados para um mundo outro - tão surpreendente e desestabilizador quanto o é o recurso à metáfora acústica. Inversão importante, do óptico ao sonoro, pois resulta de um transportamento ao passado que possibilita desordenar as coordenadas do espaço e do tempo a fim de que estes se tornem determináveis no presente. Elegendo o déjà vu como a forma por excelência do ingresso no passado, o texto não pretende reencontrar no passado os "direitos de autoria" - o passado não é uma espécie de copyright do qual o presente seria só repetição e o déjà vu apenas Erlebniss (lembrança). O presente é, de uma só vez, capaz de nos despertar (wechend) quanto de ser ele mesmo despertado (gewegt) com o que se invertem as relações do tempo, mesmo por que somos, a um só tempo, a infância, a maturidade, a adolescência - quer dizer, memória.

$\mathrm{O}$ déjà vu - com sons ou vozes - nos surpreende como advertências de um mundo no qual não podemos adentrar ou, pelo menos, nele ainda não se ingressou. Uma Erlebniss (vivência) do passado que domine nossa consciência atual não é um déjà vu, mas apenas uma lembrança. O sinal distintivo do déjà vu é o de "misturar-se" aos "arcos do passado", revolucionando nossas relaçōes com o tempo. É esta a razão pela qual Benjamin utiliza a palavra choque em francês - choc 
- e o faz, ampliando seu campo semântico: embate, choque, colisão mas sob um aspecto inesperado, como a metáfora acústica. O choque não provoca o abalo mas é por ele produzido - a colisão é a condição de possibilidade de reconhecimento do choque. Desse paradoxo (da imagem visual e daquela sonora) nasce o Jetztzeit benjaminiano da iluminação profana, da "presença de espírito". O déjà vu quando pensado sob o aspecto da vivência deixa escapar o essencial do passado que é a súbita iluminação visionária do futuro no presente. Motivo pelo qual a luva "esquecida em nosso quarto" é cópia (Gegenbild) do eco porque ressoa no presente mas provém do futuro. O déjà vu só revela a verdade do passado se a ele se acrescenta o futuro - futuro que nāo será visto como aquilo que virá até nós mas como algo que já esteve entre nós. Há sempre algo do passado que nos ultrapassou e não chegou a ser apreendido, havendo assim, em permanência algo ainda por viver - que é freqüentemente perdido quando se chega ao sentido de um acontecimento tarde demais. Se, no entanto, há sempre e insistentemente algo por viver, é possível de o já vivido ser resgatado no futuro, numa sobreposição de tempos distantes, numa simultaneidade de passado e futuro, invertendo a concepção tradicional do déjà vu como "ilusão do já acontecido" ". Para Benjamin, não se pode diferenciar no déjà vu um "original" de uma "cópia", o presente não é simples "reflexo" do passado, sendo-lhe inferior por ser uma ilusão. Invertendo-se o fenômeno visual em sonoro - vozes ou ecos - é possível desestabilizar a relação entrè o passado e o presente a favor do passado do qual o presente é o eco, o "clínamen" (cf. Rosset, 1989). Há no déjà vu uma dupla presença misteriosa: possui o caráter de uma memória, mas é simultaneamente um eco. O déjà vu - do qual a metáfora acústica é o emblema - é memória involuntária, dá-se no tempo entrecruzado e não constitui simples ocasião de recordação. Nele, o tempo atual é também passado, contém o que acontece como já acontecido e, o que se vive, como já vivido: seu conteúdo reside inteiramente no passado: "a felicidade capaz de suscitar nossos anseios está, por inteiro, no ar que respiramos, nos homens com os quais poderíamos ter conversado, nas mulheres que poderiam ter-se entregue a nós (...). $\mathrm{O}$ mesmo ocorre com a imagem do passado da qual a história se apodera. Ela traz consigo um enigmático índice que o impele à redenção. Pois não somos tomados por um sopro no ar respeitado antes? Não existem nas vozes que escutamos, ecos daquelas que emudeceram?" (Benjamin, 1980b, Tese II). O déjà vu é uma modalidade de repetição do tempo que não confere qualquer inferioridade ontológica seja ao presente, seja se trate do passado; pode ter acontecido no passado tanto quanto se apresenta pela primeira vez. Aqui, a repetição não é cópia, como na história a-histórica. A repetição histórica não apenas a naturalizou como também "carrega" a antigüidade "como um mau espírito que teria vindo importuná-la em seu sono" (Idem, p. 470). Esta história é história fisicalista mas também história 
como catástrofe e destino: "onde há destino, uma parte da história tornou-se natureza” (Benjamin, Tese VII, p. 249). Destino e natureza são sinônimos quando desconhecem seu caráter traumático, a seqüência necessariamente catastrófica do descenso histórico - quando a repetição mítica é a fisionomia própria da modernidade. Repetição, pois: necessidade compulsiva de criar o novo tal como a produção regida pelo mercado capitalista o determina. Este é a forma inautêntica do "atual", é sonolência e inaptidão para produzir o novo, sendo sua mais visível letargia a moda: renovação fictícia, sua repetição sazonal testemunha a estagnação de uma sociedade incapaz de renovação: uma coletividade que sonha ignora a história. Para ela, os acontecimentos se desenrolam segundo um curso sempre idêntico e sempre "ultra-novo". Para o século XVII como para o XX, a alegoria ${ }^{4}$ não é uma figura retórica mas método de conhecimento do presente ${ }^{5}$, havendo uma aliança entre alegoria e melancolia: "a melancolia é o sentimento de uma subjetividade que, imersa em si mesma, constrange as coisas a retirarem-se do mundo, reduzindo-o a fragmentos e ruínas, relegando-as à fixidez alucinatória e espectral do detalhe; isola-as; fazendo-as estranhas ao fluxo da vida (...). A ótica do melancólico é a do profundo. A atividade do alegorista (ou a do historiador) é, propriamente, uma descida aos abismos daqueles significados que perdemos; mas é exatamente este mundo enquanto se contrai e se apaga em um universo vazio de sinais. Quem desce aos abismos é tomado da vertigem que irrompe na ordem da passagem de um a outro, deixando escapar aquele ponto de apoio até abandonar-se como que suspenso sobre o abismo. Na melancolia - que parece encerrar-se sobre si mesma - uma intensa nostalgia do profundo se insinua - isto é, a melancolia é uma espécie de vertigem permanente: a escuridão e a névoa de Saturno, planeta da melancolia" (Ferruccio, 1976).

A melancolia abre uma crise na teoria tradicional do conhecimento como adequatio intellectus et rei, o tempo a contradiz, já que a crise indica o tempo oportuno - aquele antes do qual nada foi consumado e depois do qual tudo estará perdido. Benjamin encontra na "gestão" espontânea das ruas de Moscou - quando de sua estada entre dezembro de 1926 e janeiro de 1927, a experiência de uma "iluminação profana", "imagem dialética", "presença de espírito". Em contrapartida ao controle estatal dos espaços - que dissolveu a noção de vida privada - os pobres das ruas são seus "filhos legítimos". Se nas passagens de Paris, convivem incestuosamente jogadores, desocupados, prostituição, as ruas frias de Moscou revelam um sentido inesperado de proteção e abrigo: "(os pobres das ruas) conhecem com precisão um recanto ao lado de certa loja onde podem se aquecer por dez minutos; sabem onde buscar, em um determinado dia da semana e em hora certa, pedaços de pão; sabem onde há vaga para dormir em camas amontoados 
uns sobre os outros. Com centenas de variações, transformam a miséria numa grande arte" ("Moscou". In: Benjamin, 1994).

No descompasso entre memória e consciência brilha a iluminação: “assim como para Goethe a esperança era a palavra derradeira, para Benjamin ela é a primeira palavra da redenção".

ABstracr: The aim of this article is to demonstrate how Walter Benjamin deals with the concept of allegory as applied to the 18 th century as well as to its modern substitute - the fetichism of merchancy. If Hamlet is the emblematic representative of melancholy, Baudelaire does the same for the mal-du-siècle. In order to understand historic time. Benjamin proposes to interpret it in the core of the cultural process of mourning, in its extreme form of expression: the ruins.

History and Nature, or Hazard and Necessity become nature morte and mourning silence of men In history: necessitarism excludes contingency (in nature) and fortune (in history). In place of the mechanized time of watches, Benjamin puts a form of time experience which expresses itself through déjà $v u$, a temporality that hesitates between the already happened and what is due to happen. One may understand history at the same time as a landscape of rememberings and the experience of a threshold.

KEY-wORDS: allegory - melancholy - destiny - fortune

\section{NOTAS}

1. Que se lembrem, aqui, as circunstâncias nas quais Benjamin constrói seu Origem do Drama Barroco Alemão. Publicado em 1928, o filósofo faz o século XVII contemporâneo do nosso tempo, chamando a atenção para a quase inexistência do barroco literário no curriculum universitário por constituir um verdadeiro ato de esquecimento ideológico. Não apenas a capital da Alemanha, quando da proclamação da República em 1919, não é Berlim - onde ocorreram os fatos mais importantes da derrubada da monarquia dos Hohenzollern - como passa a ser Weimar, a capital de Goethe e do classissismo alcmão. A uma Alemanha que vive o conflito que levaria à II Guerra Mundial, com crimes, traições e perseguições políticas, a História oficial celebra a harmonia, o equilíbrio $\mathrm{c}$ a linguagem clara e simbólica em contrapartida à alegórica e desestabilizadora dos dramas barrocos. O trabalho de reflexão lutuosa de um tempo de homens partido é também o 
moderno e suas representantes culturais: "não há nenhum documento de cultura", anota Benjamin, "que não seja também o de barbárie (...). Não nasceram apenas dos esforços dos grandes gênios que os criaram mas, também, da anônima corvéia imposta aos contemporâneos desses gênios" (Benjamin, 1980b).

2. As noções de Destino e Caráter remetem às relações entre necessidade e fatalidade, por um lado, ao ato livre de outro, abrindo-se, pois, a questão acerca da responsabilidade na ação, a possibilidade da criação do próprio destino e da própria história (Aristóteles, Livro II e VI da Ética a Nicômaco; Cícero, De finibus, II, 13). Com Aristóteles configura-se a separação entre razão teórica e razão prática, a primeira é reflexão acerca do que é Eterno - a transcendência do divino; quanto à razão prática, trata-se da atividade dos homens que só contam com suas próprias forças para organizar suas vidas: a ação não tem mais nada a esperar da teoria, isto é, da contemplação". Aubenque refere-se à assimilação da razão prática à ação como "fabricação", o que resultará nas filosofias iluministas da história e sua crença no progresso. São três seus principais temas: a época presente representa a idéia de que o futuro é adimensào do novo e sem precedente nas épocas passadas; o que vem depois é sempre uma mudança necessariamente para melhor e, por último, os homens dominam cada vez mais os acontecimento, estando, conseqüentemente sempre mais aptos a fazerem a história.

3. Vê-se que Infância Berlinense não se integra à concepção materialista clássica da história; sua concepção do tempo como Jetzteit, presença de espírito, déjà vu difere da idéia segundo a qual o instante da ação retira sua poesia só do futuro - como a do Dezoito Brumário de Marx. Para Benjamin, a revolução é o "salto tigrino" no céu livre da História no tempo oportuno (Benjamin, 1980b, Tese VII).

4. Alegoria é um termo que pode ser compreendido a partir de sua derivação etimológica: do grego, a alegoria constrói-se como "destino outro" - allos, e de agoreuein - falar em público. Pode-se também, considerá-la como a relação entre "outro" e "discurso": "falar de outra maneira que não publicamnete": alläh - outro, diferente; agoreuein - falar na Ágora ou em assembléias públicas: alegoria é "falar de outra maneira a não ser compreensivel a todos". A alegoria é uma representação caracterizada como outra em relação ao sentido, da mesma forma que, em uma leitura, o figurado ou o literal de um texto é visto como indicação de um outro significado. Dito de outro modo, o significado - e não o significante - é visto como outro enquanto o significante apresenta-se em sua ambigüidade (Sigrid, 1996, p. 96 e 99).

5. Algo aqui pode ser aproximado da concepção agostiniana do tempo, onde não há tripartição passado - presente - futuro, mas antes o presente do passado (a recordação), o presente do presente (a visão que está disponível a reconhecê-lo) e o presente do futuro (a espera) (cf. Confissões, Ed. Porto, 1948) 


\section{REFERÊNCIAS BIBLIOGRÁFICAS}

BENJAMIN, W. Gesammelte Schriften. Frankfurt, Suhrkamp, 1980 (a).

"Sobre o Conceito de História" in Illuminationen. Frankfurt, Suhrkamp, 1980 (b).

Origem do drama barroco alemão. São Paulo, Ed. Brasiliense, 1984.

"Imagens do Pensamento", in Documentos de Cultura, documentos de barbárie: escritos escolhidos. Seleção e apresentação de Wille Bolle, São Paulo, Ed. Cultrix/USP, 1985.

Rua de Mão Única. São Paulo, Ed. Brasiliense, 1994, $4^{a}$ ed.

- Critiche e recensione. Turin, Einaudi. (C.R.)

BERGSON, H. Les deux sources de la morale et de la réligion. 1939.

BOLLE, W. Fisiognomias da metrópole moderna. São Paulo, EDUSP/FAPESP, 1994.

CHAUf, M. "Contingência e Necessidade". In: A Crise da Razão. São Paulo, Cia. das Letras/Funarte, 1996.

DEBORD, G. A sociedade do espetáculo, Rio de Janeiro, Ed. Contraponto, 1997.

DESCARTES, "Princípios de Filosofia". In: Oeuvres. Adam et Tannery, IX.

DOMINGUES, I, O fio e a trama. UFMG/Iluminuras, 1996.

HORKHEIMER e ADORNO. Dialektik der Aufklärunged. Fischer Verlag, 1980.

JÜNGER. Le Travailleur. Ed. Christian Borgois, 1989.

MASINI, F. "Melancholia illa allegorica”. In: Quaderni di Critica. Roma, 1976.

MATTHIEUSSENT, B. Expositions: pour Walter Benjamin. Paris, Ed. Fourbin, 1994.

MOTTA, Leda Tenório. Lições de literatura francesa. Ed. Imago, 1997.

NIETZSCHE, F. Genealogía de la Moral e Más allá del Bien y del Mal. Buenos Aires, Ed. Aguilar, 1947.

ROSSET, C. A Anti-Natureza. Rio de Janeiro, Ed. Espaço e Tempo, 1989.

ROSSI, P. Os filósofos e as máquinas. São Paulo, Cia das Letras, 1989.

STEINBERG, M. Walter Benjamin and the Demands of History. Cornell University Press, 1996.

SIGRID, W. The other in allegory; a prehistory of the modernity in the Barroque. New York, Londres, Routledge, 1996. 